\title{
Roundtable Discussion \\ from the Annual Desmond Tutu Centre \\ for Religion and Social Justice Public Lecture on Economies of Violence
}

\section{Sa'diyya Shaikh \\ Fatima Seedat \\ Farah Zeb}

\section{Introduction}

In South Africa, the month of August is marked by two significant events in the country's history: The anti-apartheid women's march which happened on 9 August 1956 and the Marikana massacre on 16 August 2012, in which 34 miners were killed by the police at the Lonmin mine. These events bring up for scrutiny the "Economies of Violence" that continue to sustain the indignity and the poverty which women, queer people, and marginalised black people in South Africa disproportionately experience. The Covid-19 pandemic has simply exacerbated this reality. Recognising the multiple factors which shape access to justice such as gender, religion, race, and class, the Desmond Tutu Centre for Religion and Social Justice annually convenes various public and scholarly conversations on these subjects. The 2021 symposium considered the importance of resisting/transcending the epistemic violence which demands that black women focus on research and teaching that is perpetually located within pain and suffering. By doing so, the keynote presenter, Prof Sa'diyya Shaikh, and respondents, Dr Fatima Seedat and Dr Farah Zeb, also considered the spiritual reflections and practices which bring us joy and rest. 